\title{
Optimization of isothermal transformation period for austempered ductile iron
}

\author{
Optymalizacja okresu przemiany izotermalnej \\ podczas hartowania izotermalnego \\ żeliwa ciągliwego perlitycznego
}

\begin{abstract}
The present paper examines and compares the influence of austempering parameters such as temperature and time on the isothermal transformation and microstructural changes of ductile iron. To identify the compositional and structural changes during an isothermal transformation, a very wide austempering period is chosen at a transformation temperature for the precise determination of the process window. XRD, optical, and scanning electron microscopic techniques are exploited to identify and analyze the changes in the austempered structure, at austempering temperatures of $250^{\circ} \mathrm{C}$ and $400^{\circ} \mathrm{C}$. The various structural parameters like austenite volume fraction $\left(V_{\gamma}\right.$, its carbon content $\left(C_{\gamma}\right)$, lattice parameter, and the average cell size of the ferrite are ascertained. Electron backscattered diffraction (EBSD) analysis is used to identify the carbide precipitation obtained due to the austempering Stage-II reaction. It is noticed that, at the end of the austempering Stage-II reaction, there is a significant reduction in the volume fraction of stabilized austenite and it's carbon content, as the microstructure at this stage not only contains ausferrite but also additional precipitated iron carbides. With an increase in austempering time, the austenite and ferrite volume fraction increase until the austenite becomes stabilized with sufficient carbon. The increase in the lattice parameter of the austenite during austempering corresponds to the rise in carbon content within the austenite. A rise in the austempering temperature leads to a reduction in the volume fraction of the ferrite and an increase in the stabilized austenite volume fraction. The optimum isothermal transformation period for austempered ductile iron is established, based on the period during which the maximum content of the austenite volume fraction, its carbon, the lattice parameter, and the average cell size of the ferrite are maintained.
\end{abstract}

Keywords: ADI, stabilized austenite, process window, EBSD, austempering

\section{Streszczenie}

W pracy przedstawiono badania dotyczące wpływu parametrów hartowania izotermicznego takich jak temperatura i czas na izotermiczną transformację i zmiany mikrostrukturalne żeliwa

Prashant Parhad Associate Professor: Kavikulguru Institute of Technology and Science, Department of Mechanical Engineering, Ramtek, India, Ajay Likhite Associate Professor, Jatin Bhatt Associate Professor, Dilip Peshwe Professor: Visvesvaraya National Institute of Technology, Department of Metallurgy and Materials Engineering, Nagpur, India; parhad_pp@yahoo.co.in 
sferoidalnego. W celu określenia zmian strukturalnych i składu chemicznego podczas przemiany izotermalnej został dobrany bardzo szeroki okres hartowania izotermalnego, co pozwoliło na precyzyjne określenie warunków procesu. Zastosowano techniki takie jak dyfrakcja promieniowania rentgenowskiego (XRD), mikroskopia świetlna i skaningowa mikroskopia elektronowa, aby zidentyfikować i przeanalizować zmiany strukturalne po hartowaniu w temperaturach $250^{\circ} \mathrm{C}$ i $400^{\circ} \mathrm{C}$. Określono różne czynniki strukturalne, takie jak udział objętościowy austenitu $(V \gamma)$, zawartość węgla w austenicie $(C \gamma)$, stała sieciowa oraz średnia wielkość komórki elementarnej ferrytu. Dyfrakcję elektronów wstecznie rozproszonych (EBSD) zastosowano do zidentyfikowania wydzieleń węglików powstałych wskutek reakcji drugiego etapu podczas hartowania izotermalnego. Nie zauważono, aby z końcem reakcji drugiego etapu hartowania izotermalnego nastąpił widoczny spadek udziału objętościowego ustabilizowanego austenitu i zawartości w nim węgla, ponieważ mikrostruktura na tym etapie nie tylko zawiera ausferryt, lecz również wydzielenia węglików żelaza. Wraz z wydłużeniem czasu hartowania udział objętościowy austenitu i ferrytu wzrasta aż do momentu, kiedy austenit zostanie ustabilizowany odpowiednią ilością węgla. Zwiększenie stałych sieciowych austenitu w trakcie hartowania izotermalnego prowadzi do zmniejszenia udziału objętościowego żelaza i wzrostu udziału ustabilizowanego austenitu. Optymalny okres transformacji izotermalnej hartowanego żelaza sferoidalnego został określony na podstawie okresu, podczas którego maksymalna zawartość udziału objętościowego austenitu, zawartego w nim węgla, stałej sieciowej i średniej wielkości komórki elementarnej ferrytu była utrzymana.

Słowa kluczowe: ADI, stabilizowany austenit, warunki procesu, EBSD, hartowanie izotermalne

\section{Introduction}

Austempered ductile iron (usually known as 'ADI') has gained recognition among producers as an important structural material. Though ADI is a well-known material, continuous research has been carried out to improve its properties and to understand the mechanism that governs ADI formation [1, 2]. ADI is produced by subjecting ductile iron (DI) to austempering heat treatment that involves austenitization and isothermal transformation in the bainitic temperature region, followed by air-cooling. The subsequent microstructure of the ADI matrix mainly consists of acicular ferrite and the carbon stabilized austenite. During the isothermal transformation, an alloy passes through three segments. In the first segment, the nucleation of the ferrite takes place at the graphite/ austenite interface. As the solubility of the carbon in ferrite is very low, it rejects the carbon in the surrounding austenite. Thus, the growth of ferrite causes an enrichment of carbon in the austenite with the passage of austempering time. This leads to the gradual stabilization of austenite so that it will exist in the structure even after cooling. But, due to short austempering time, a very small amount of carbon diffusion takes place in the austenite in this stage; hence, the stability of the austenite is not sufficient, as it gets transformed to martensite during cooling). In the second segment, the concentration of carbon in the austenite gradually increases to its maximum equilibrium level, as more 
and more carbon is rejected from the ferrite to the surrounding austenite, causing its thermal stability; by which, the martensitic transformation is avoided during the cooling to room temperature. This segment is characterized by the presence of a unique ausferritic structure; in general, this is believed to be the best structure that is responsible for the attribution of remarkable properties in the ADI. In the third and last segment, the amount of the stabilized austenite starts to decline because of its further transformation into the ferrite and iron carbide [3]. Hence, depending upon the isothermal transformation time, some amount of martensite or number of carbides can appear, resulting in a degradation of the mechanical properties [4]. The combination of plasticity and toughness are the most-desirable properties required in wide applications, such as parts in automotive, construction, agriculture, and railroad components worldwide. In ADI, these properties are obtained when the austenite volume fraction, its carbon content, and lattice parameter are at their maximum levels. This coincides with the second segment of the isothermal transformation period and is recognized as the "optimum isothermal transformation period" [5].

Rundman reported [6] that reducing the austenitization temperature from $927^{\circ} \mathrm{C}$ to $871^{\circ} \mathrm{C}$ lowers the matrix carbon content by $0.16 \mathrm{wt} . \%$, which results in an increase in the rate of the ausferrite reaction by about a factor of two. Tanaka and Kage [7] explained the thermodynamic reason behind this increase in the reaction rate. However, once the austenitization temperature is selected, it is the austempering temperature and time that decides the final microstructure be obtained at the end of the heat-treatment process. Therefore, an understanding of the relationship between the austempering transformation and the resultant microstructure developed under variable austempering conditions is essential to appreciate and optimize the austempering parameters (such as temperature and time). The transformation response of DI during austempering depends on the very complex interaction between ductile iron chemistry, austempering temperature, and time. These factors affect both the nucleation of the Stage-I reaction and austenite decomposition during the Stage-II reaction.

$A D I$ is identified as a sustainable green alternative materia; I hence, understanding the exact mechanism of its ausferritic structure and optimizing the best combinations of the heat treatment parameters will boost the use this perspective material for various applications. Though adequate information and data is available now in the processing window of $\mathrm{ADI}$, the overall work has been initiated for the in-depth understanding of ausferritic transformations in ADI. Hence, the aim of this work is to recognize the exact mechanism of ausferrite transformation and also determine the optimum range of the transformation period. The emphasis is given on the co-relationship between the austenite volume fraction, its carbon content, the lattice parameter, and the average cell size of the ferrite obtained by subjecting $\mathrm{DI}$ to lower and higher austempering temperatures of $250^{\circ} \mathrm{C}$ and $400^{\circ} \mathrm{C}$ for varying durations. 


\section{Experimental}

The chemical composition of ductile iron used for this investigation is given in Table 1.

Table 1. Chemical composition [wt.\%] of ductile iron

\begin{tabular}{|c|c|c|c|c|c|c|c|c|c|c|c|}
\hline Grade & C.E & $\% C$ & $\% S i$ & $\% \mathrm{Mn}$ & $\% \mathrm{P}$ & $\% \mathrm{~S}$ & $\% \mathrm{Cr}$ & $\% \mathrm{Ni}$ & $\% \mathrm{Cu}$ & $\% \mathrm{Mg}$ & $\% \mathrm{Fe}$ \\
\hline DI $\left(\mathbf{C}_{\mathbf{0}}\right)$ & 4.23 & 3.53 & 2.50 & 0.44 & 0.045 & 0.010 & 0.037 & 0.008 & 0.56 & 0.050 & balance \\
\hline
\end{tabular}

The DI specimens of the stated composition are then subjected to austempering heat treatment (as shown in Figure 1).

To investigate the structural and compositional changes during the isothermal transformation, a wide range of austempering durations (particularly at $250^{\circ} \mathrm{C}, T_{A}=1 \mathrm{~h}$ to $8 \mathrm{~h}$ at an interval of $1 \mathrm{~h}$, and at $400^{\circ} \mathrm{C}, T_{A}=2 \mathrm{~h}$ to $10 \mathrm{~h}$ at an interval of $2 \mathrm{~h}$ ) were chosen. After holding the specimens for the specified duration, they are air-cooled from the austempering temperature to room temperature.

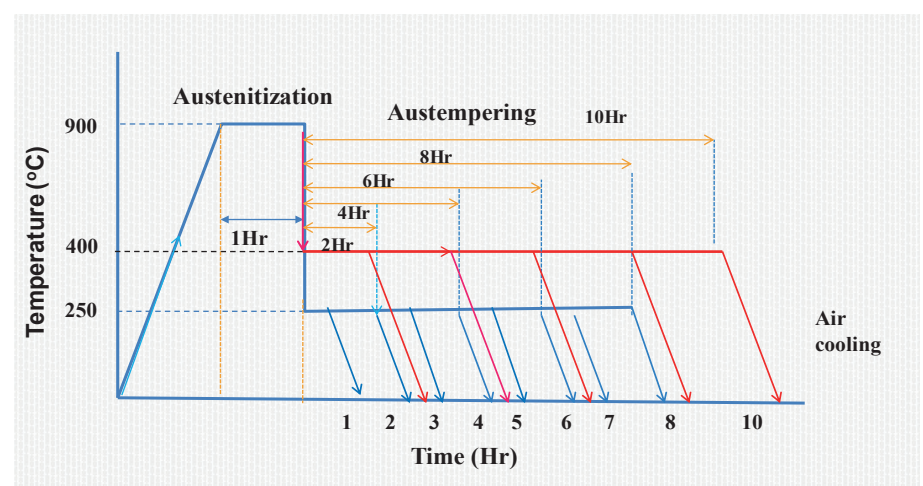

Fig. 1. Schematic of austempering treatment

The metallographic samples were prepared from test specimens after heat treatment to investigate the changes in microstructure (the complete details of the sample preparation have been described in our previous work) [8]. The X-ray diffraction (XRD) technique was used to determine the amount of carbon-stabilized austenite and its carbon content. To compute the carbon stabilized austenite content of the ADI, a simple method described by Senczyk [9] and an equation proposed by Aranzabal [10] for calculating the carbon dissolved in austenite is used. Then, the austenite lattice parameter $\left(\alpha_{\gamma}\right)$ is determined by the well-known equation stated by Cullity [11], while the average size of the ferrite cell is calculated by using Equation (1) [11]. 
where:

$$
d=\frac{0.9 \lambda}{\beta \cos \theta}
$$

$\mathrm{d}$ - average particle size of ferrite [nm],

$\lambda$ - wavelength [nm],

$\beta$ - diffraction line broadening, measured in the middle of its maximal intensity [rad],

$\theta$ - the angle of the interference line determined from the diffraction pattern in $\left[{ }^{\circ}\right]$.

Vickers hardness test is used to measure the bulk hardness of the heat-treated specimen. Details of the sample preparation, measurement conditions (and determination of carbon content), lattice parameter, and volume fraction of the austenite have all been described in previous works [8].

\section{Results and discussion}

The austempering transformation in $\mathrm{DI}$ is represented by a two-stage reaction; one with austenite $(\gamma)$ decomposing to acicular ferrite $(\alpha)$ and high carbon austenite $\left(\gamma_{\mathrm{HC}}\right)$ (i.e., $\gamma \rightarrow \alpha+\gamma_{\mathrm{HC}}$ ) followed by two, further high carbon austenite decomposition to ferrite and carbide (i.e., $\gamma_{\mathrm{HC}} \rightarrow \alpha+$ carbides).

\subsection{Austempering temperature and time}

To develop the desired microstructure in ADI, the proper selection of austempering temperature is an important step. The ferrite and carbon-enriched austenite are the typical constituents of DI heat treated at a higher temperature [12]. If the temperature is low, then it retards the rejection of carbon from the ferrite, therefore resulting in the formation of transitional carbides within the ferrite [13]. Hence, at a lower temperature, the structure consists of small amounts of austenite $\leq 10 \%$, while at a high temperature, it can be as high as $40 \%$. The correct austempering time should result in structures free from martensite (characteristics of a too-short holding time) and precipitated carbides (characteristics of a too-long holding time) as the results in degradation of mechanical properties [14].

\section{Dl austempered at $250^{\circ} \mathrm{C}$}

The as-cast microstructure of the ductile iron consists of graphite nodules embedded in ferritic envelops with the pearlitic matrix as shown in Figure $2 a$, while Figure $2 b$ illustrates the microstructure in an unetched condition revealing the uniform distribution of graphite nodules dispersed throughout the matrix. A nodule count of $512 \mathrm{nods} / \mathrm{mm}^{2}$ is obtained for a cylindrical specimen of $20 \mathrm{~mm}$ in diameter. 
a)

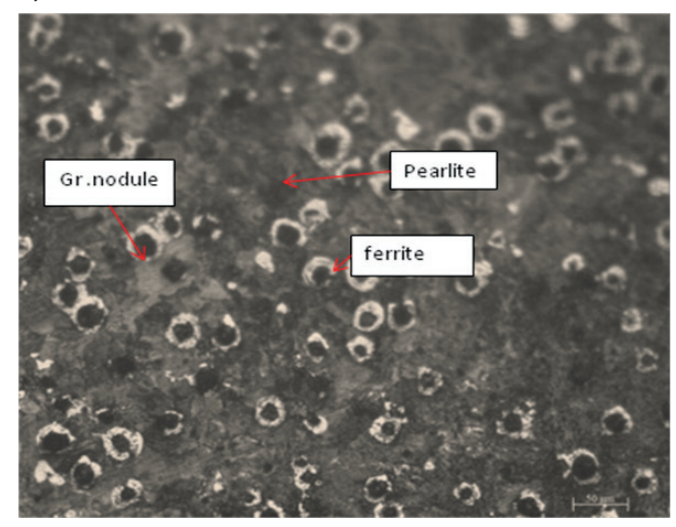

b)

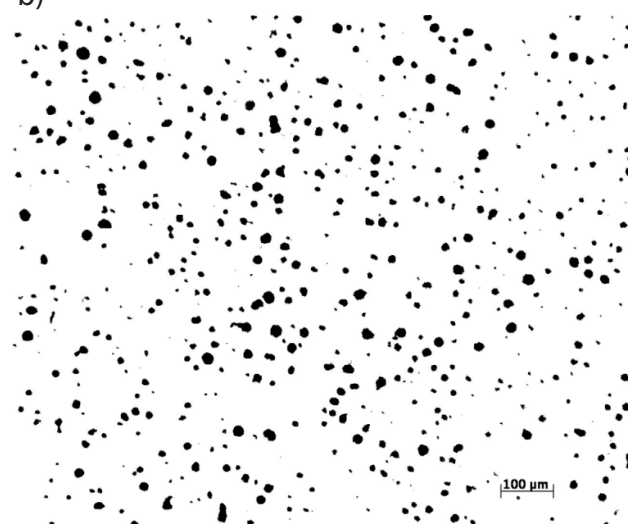

Fig. 2. As-cast microstructure of ductile iron: a) graphite nodules embedded in ferritic envelope with pearlitic matrix [8]; b) graphite nodules uniformly distributed in matrix (unetched condition)

\section{Aver age cell size( $\alpha$ ) of ferrite Vs Austempering time}

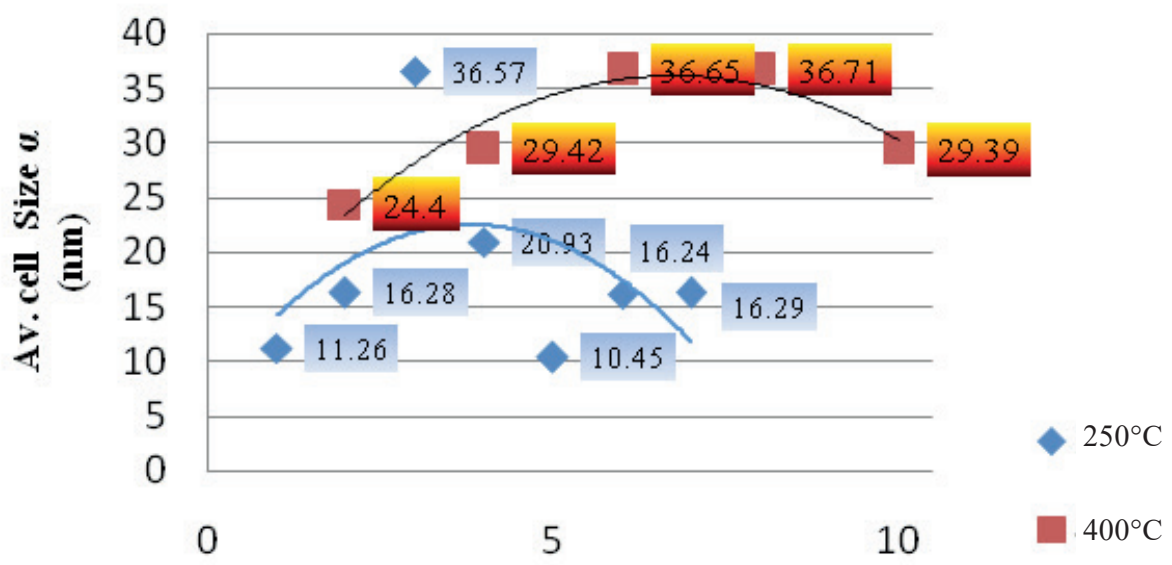

Austempering Time (Hr)

Fig. 3. Effect of austempering time on average cell size of ferrite austempered at $250^{\circ} \mathrm{C}$ and $400^{\circ} \mathrm{C}$

The austempering temperature and time influences both the transformation kinetics as well as the mechanism of transformation; hence, their response is extremely complicated. At the lower temperature, the nucleation rate was high, but the diffusion and growth rates were low; therefore, a significant amount of ferrite nucleation took place, 
and finer cell sizes of the ferrite were accordingly obtained. This effect is evident in Figure 3 , which shows the influence of austempering time on the average cell size of ferrite austempered at $250^{\circ} \mathrm{C}$ and $400^{\circ} \mathrm{C}$. The cell size of the ferrite obtained in DI austempered at $250^{\circ} \mathrm{C}$ (blue dots) is much smaller as compared to $400^{\circ} \mathrm{C}$.

For DI austempered at $250^{\circ} \mathrm{C}$, the acicular ferrite needles begin to nucleate in the first segment of austempering, primarily at the graphite/austenite interface (as these are potent sites for nucleation and growth). This effect is evident in optical image Figure 4a, while the acicular morphology of ferrite is revealed in SEM image Figure $4 \mathrm{~b}$. The calculated values of the austenite lattice parameter, its carbon concentration, and the amounts of stabilized austenite as well as ferrite at changing austempering durations are reported in Table 2.

a)

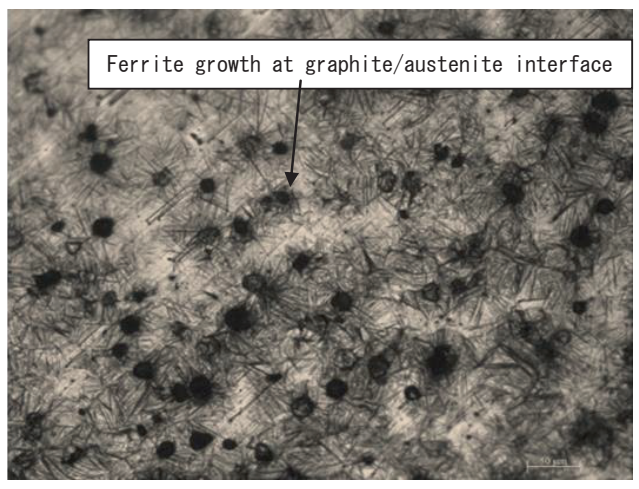

b)

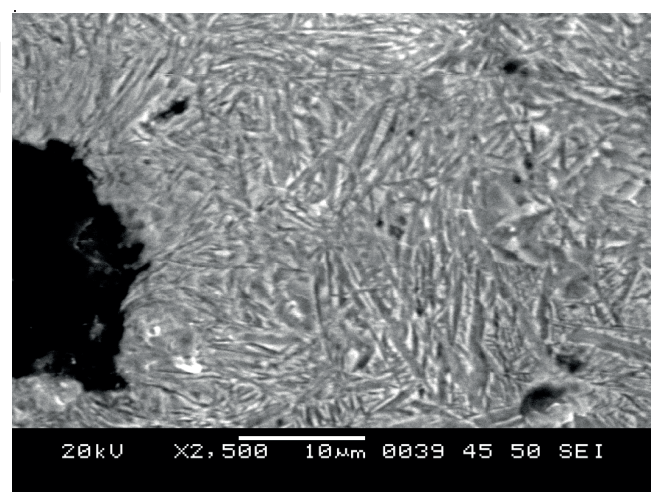

Fig. 4. Microstructure of DI -250-1 h (etched with 2\% Nital): a) optical microscope - black arrow indicating growth of ferrite on graphite-austenite interface; b) SEM image

The effect of the austempering duration on (a) the lattice parameter and carbon content of austenite, (b) the volume fraction of C-stabilized austenite, and (c) the average cell size of the ferrite is revealed in Figures 5-7, respectively. The entire mechanism of this austempering transformation is discussed in detail in research paper [8].

It was observed that, beyond $3 \mathrm{~h}$ of isothermal transformation up to a $6 \mathrm{~h}$ duration:

a) the lattice parameter and carbon content of austenite essentially remain unvarying (i.e., $\alpha_{\gamma}=6.234 \pm 0.006$ and $\% C=1.71 \pm 0.125$ );

b) the content of C-stabilized austenite reduces marginally but stays steady in essence (i.e., \%C-stabilized austenite $=19.94 \pm 2.95$ );

c) similarly, the average cell size of ferrite $=18.34 \pm 2.10 \mathrm{~nm}$;

d) the hardness of the specimens remain almost stable (HV10 $=596 \pm 25)$ in this segment. 


\begin{tabular}{|c|c|c|c|c|c|c|c|c|c|c|}
\hline \multirow{2}{*}{ 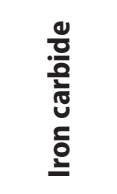 } & $\begin{array}{l}\cup \\
\stackrel{+}{+}\end{array}$ & $*$ & 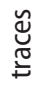 & $*$ & 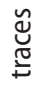 & $*$ & 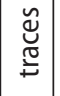 & 요 & $\stackrel{\llcorner}{\stackrel{2}{N}}$ & $\bar{n}$ \\
\hline & 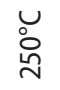 & 르 & 르 & 으 & $\bar{\infty}^{\infty}$ & $\stackrel{\llcorner}{\circ}$ & $\stackrel{8}{\circ}$ & 话 & $*$ & $*$ \\
\hline \multirow{2}{*}{ 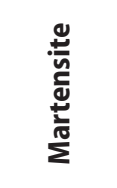 } & $\begin{array}{l}\cup \\
\stackrel{+}{+}\end{array}$ & $*$ & $\lesssim$ & $*$ & $\stackrel{\infty}{\sim}$ & $*$ & $\begin{array}{l}\widetilde{\mathscr{J}} \\
\stackrel{\widetilde{J}}{\leftrightarrows}\end{array}$ & 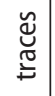 & $*$ & $*$ \\
\hline & $\begin{array}{l}\text { 呤 } \\
\text { ڤ్ }\end{array}$ & $\stackrel{m}{m}$ & શે & $\stackrel{\circ}{\circ}$ & 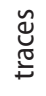 & $\begin{array}{l}\mathscr{\Xi} \\
\stackrel{\Xi}{\Xi}\end{array}$ & 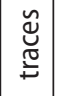 & $\begin{array}{l}\widetilde{\Xi} \\
\stackrel{\widetilde{J}}{ \pm}\end{array}$ & $*$ & $*$ \\
\hline \multirow{2}{*}{ 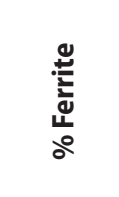 } & $\begin{array}{l}\cup \\
\stackrel{\leftrightarrow}{+}\end{array}$ & $*$ & $\begin{array}{l}0 \\
\infty \\
\infty \\
0\end{array}$ & * & 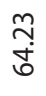 & * & 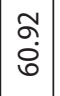 & $\stackrel{m}{\stackrel{m}{i}}$ & $\underset{N}{\stackrel{N}{N}}$ & $\frac{0}{\stackrel{1}{N}}$ \\
\hline & 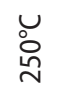 & $\bar{\infty}$ & $\stackrel{\infty}{\stackrel{\infty}{\infty}}$ & हi & 菅 & $\stackrel{n}{0}$ & $\frac{\bar{x}}{\bar{\pi}}$ & సֶ. & $*$ & $*$ \\
\hline \multirow{2}{*}{ 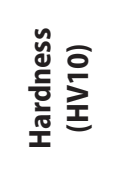 } & 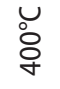 & * & $\stackrel{\text { ని }}{+}$ & $*$ & $\stackrel{\stackrel{n}{n}}{\sim}$ & $*$ & $\underset{\sim}{\tilde{\sigma}}$ & 앙 & হ্ & そ \\
\hline & $\begin{array}{l}\cup \\
\text { ○े }\end{array}$ & సิ & ๖ำ & సơ & $\stackrel{m}{\kappa}$ & ๙ & $\underset{\mho}{ }$ & ஓ্ণ & $*$ & $*$ \\
\hline \multirow{2}{*}{$\begin{array}{l}\gamma \\
\frac{0}{0} \\
\stackrel{N}{E} \\
\frac{N}{n} \\
\overline{\bar{U}}\end{array}$} & ○े & $*$ & $\stackrel{+}{\sim}$ & $*$ & ปั. & $*$ & $\begin{array}{l}n \\
0 \\
\dot{0} \\
m\end{array}$ & స઼ & $\begin{array}{l}\overline{\hat{n}} \\
\dot{m}\end{array}$ & $\begin{array}{l}\tilde{m} \\
\text { సे }\end{array}$ \\
\hline & $\begin{array}{l}\text { ○े } \\
\text { ڤ్ }\end{array}$ & $\stackrel{\stackrel{?}{ְ}}{\rightleftharpoons}$ & 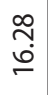 & $\begin{array}{l}\hat{n} \\
\stackrel{0}{n}\end{array}$ & 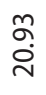 & \begin{tabular}{l}
$n$ \\
\multirow{2}{0}{} \\
0 \\
0
\end{tabular} & 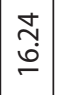 & શิ & $*$ & $*$ \\
\hline \multirow{2}{*}{ 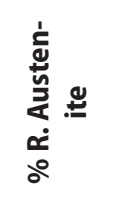 } & ○े & $*$ & ma & $*$ & $\stackrel{\hat{N}}{\stackrel{\sim}{\sim}}$ & * & 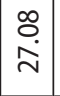 & ồ & $\begin{array}{l}\infty \\
\stackrel{0}{0} \\
0\end{array}$ & İ \\
\hline & $\begin{array}{l}\text { ○े } \\
\text { ڤે }\end{array}$ & $\stackrel{\leftrightarrow}{+}$ & $\underset{N}{N}$ & $\begin{array}{l}\infty \\
\stackrel{\infty}{N}\end{array}$ & 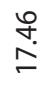 & 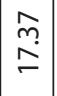 & $\begin{array}{l}\text { ğ } \\
\text { ó }\end{array}$ & $\stackrel{m}{\stackrel{n}{E}}$ & $*$ & $*$ \\
\hline \multirow{2}{*}{$\underbrace{\stackrel{0}{\delta}}_{0}$} & ঃे & * & 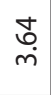 & $*$ & 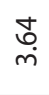 & $*$ & $\begin{array}{l}\dot{U} \\
\dot{m}\end{array}$ & $\begin{array}{l}\infty \\
\tilde{n} \\
\dot{m} \\
\dot{m}\end{array}$ & $\underset{\tilde{n}}{m}$ & $\begin{array}{l}\tilde{\sigma} \\
\dot{m}\end{array}$ \\
\hline & $\begin{array}{l}\text { :े } \\
\stackrel{\nu}{\sim}\end{array}$ & $\stackrel{\varphi}{m}$ & 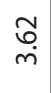 & $\stackrel{n}{\dot{m}}$ & $\hat{n}$ & $\begin{array}{l}\tilde{n} \\
\dot{m} \\
\dot{m}\end{array}$ & $\begin{array}{l}\tilde{\sigma} \\
\dot{m}\end{array}$ & $\stackrel{\bar{\sigma}}{m}$ & $*$ & $*$ \\
\hline \multirow{2}{*}{ 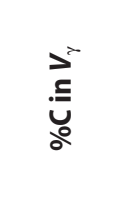 } & $\begin{array}{l}\text { ¿े } \\
\text { ஓे }\end{array}$ & $*$ & $\stackrel{m}{\stackrel{n}{i}}$ & $*$ & 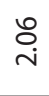 & $*$ & $\stackrel{\infty}{i}$ & $\stackrel{m}{\infty}$ & $\stackrel{\cong}{\check{E}}$ & 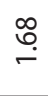 \\
\hline & $\begin{array}{l}\text { ○े } \\
\text { ڤે }\end{array}$ & 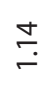 & $\underset{\sim}{\sim}$ & 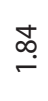 & $\stackrel{\infty}{-}$ & $\stackrel{\infty}{=}$ & 完 & $\stackrel{n}{\stackrel{n}{\longrightarrow}}$ & $*$ & $*$ \\
\hline 苞突竞 & & - & $\sim$ & $m$ & $\nabla$ & $\ln$ & 0 & $N$ & $\infty$ & 으 \\
\hline
\end{tabular}




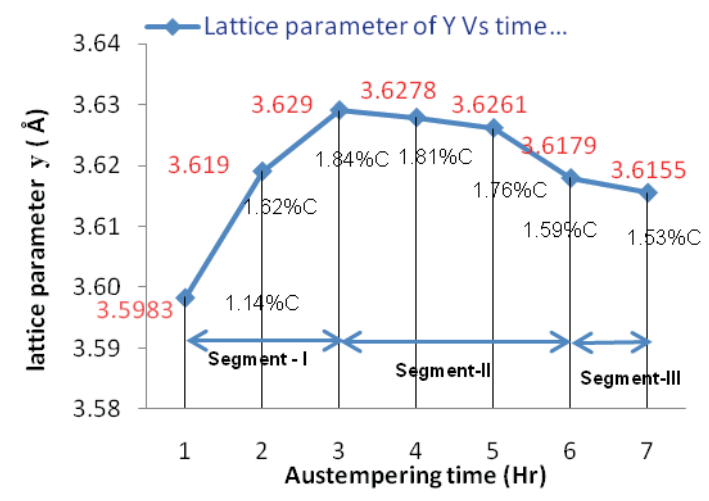

Fig. 5. Dependence of austenite lattice parameter and ' $C$ ' content in austenite on austempering transformation time [8]

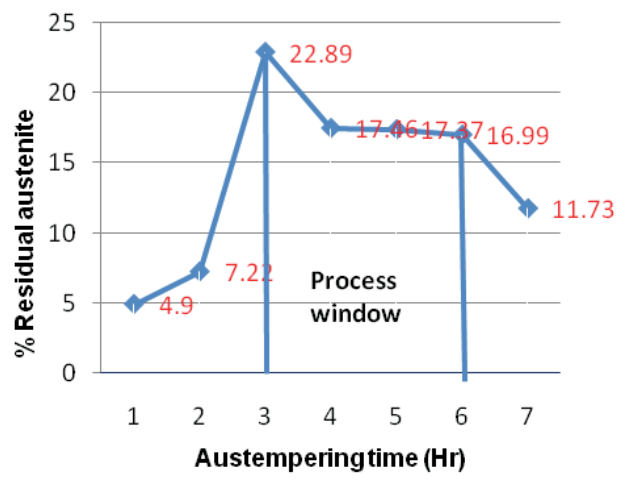

Fig. 6. Dependence of \% of carbon-stabilized Austenite on austempering transformation time [8]

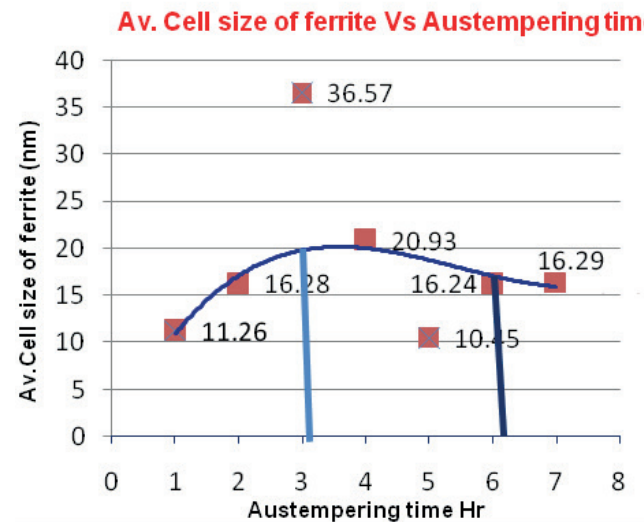

Fig. 7. Effect of transformation duration on at $250^{\circ} \mathrm{C}$ average particle size of ferrite 
This duration of 3-6 $\mathrm{h}$ is the time between the completion of Stage-I and onset of the Stage-II reaction, and it is recognized as the optimum duration of the process window. This process window is characterized by the retention of the maximum fraction of C-stabilized austenite and high carbon content in the ADI matrix and is identified as the second segment of the isothermal transformation period.

In many research papers, the bad effect of precipitation of the iron carbide in the ausferritic matrix due to extended duration was discussed. However, very few researchers have provided physical proof of the existence of it. In this investigation, iron carbide precipitates are detected, probably for the first time by the EBSD technique. Very short peaks of iron carbide are detected in the XRD analysis at $2 \theta$ values of $44.53^{\circ}$ and $44.95^{\circ}$ corresponding to planes (220) and (031), respectively, at transformation durations of $5 \mathrm{~h}$ to $7 \mathrm{~h}$ (please refer to Figure 8). For further confirmation on whether or not the carbides are formed, the EBSD analysis of DI austempered at $250^{\circ} \mathrm{C}$ for $7 \mathrm{~h}$ is studied.

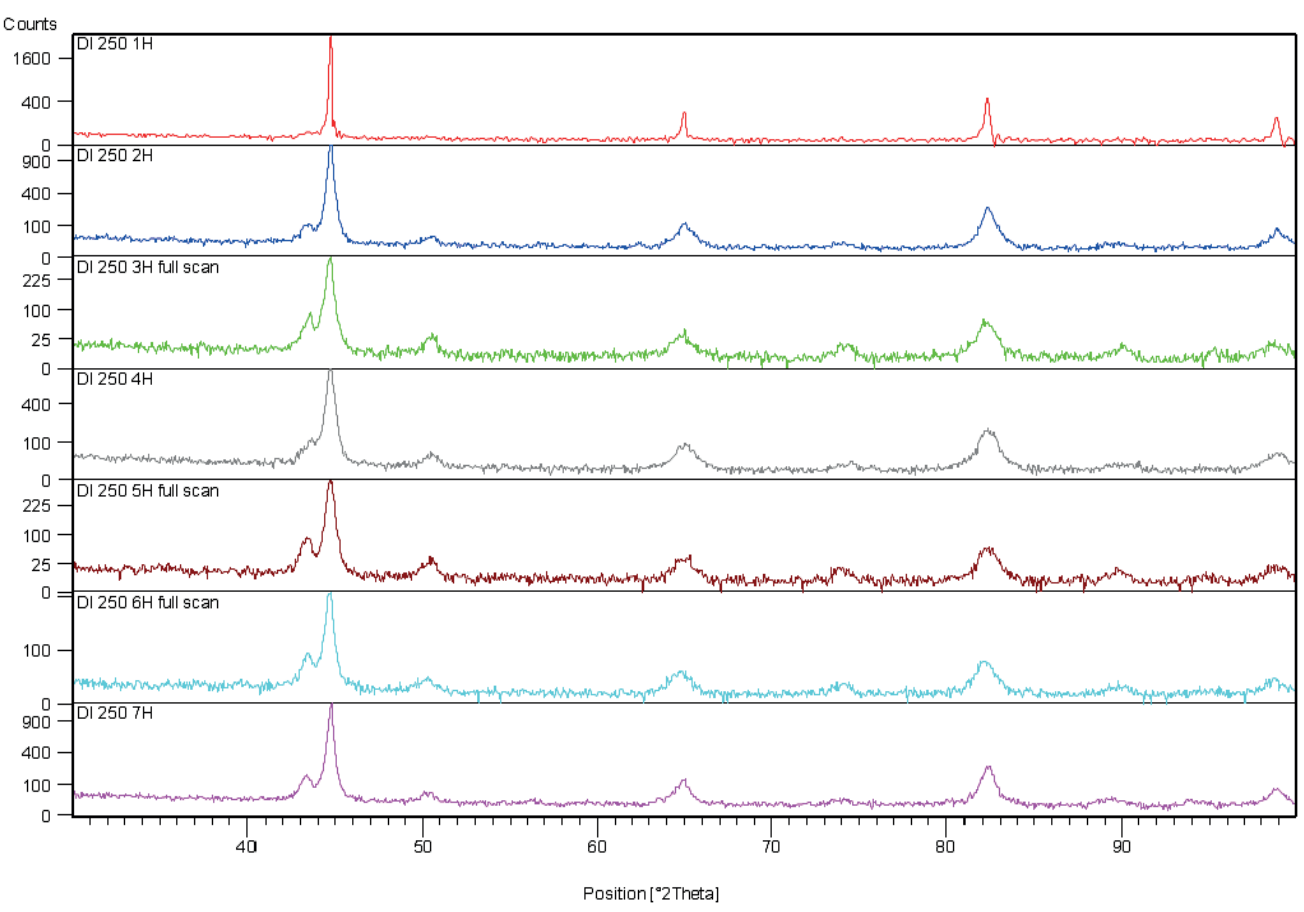

Fig. 8. XRD patterns of the specimen austempered

EBSD analysis disclosed that the fine precipitation of iron carbides took place at the ferrite/austenite interface (Fig. 9, yellow dots). The microstructure obtained at $7 \mathrm{~h}$ of isothermal holding comprises a low volume fraction of austenite (11.73 wt.\%) and high 
content of ferrite (73.27 wt.\%) as well as carbides (5.9 wt.\%). Lengthening duration again continues the dissociation of C-stabilized austenite; as a result, the microstructure of the specimen at $8 \mathrm{~h}$ shows a significant amount of ferrite and number of iron carbides. In the XRD pattern, the presence of austenite is not detected; hence, the volume fraction of austenite, its carbon content and accordingly its lattice parameter is not determined for the DI $2508 \mathrm{~h}$ specimen. During the transformation of austenite into ferrite, local supersaturation of the $\gamma$ solid solution with carbon happens, which is caused by the continuous diffusion of carbon atoms into the non-transformed austenite, resulting in the precipitation of the iron carbide. The results of the ADI matrix investigated at the different austempering times agree well with the observations of earlier research works $[5,7,15]$. It has been found that ferrite grows by displacive transformation; however, carbon atoms diffuse into the surrounding austenite or precipitate as carbides shortly once the growth is arrested $[16,17]$. The precipitation of carbides locally reduces the carbon content of the parent austenite and increases the driving force for further ferrite growth.

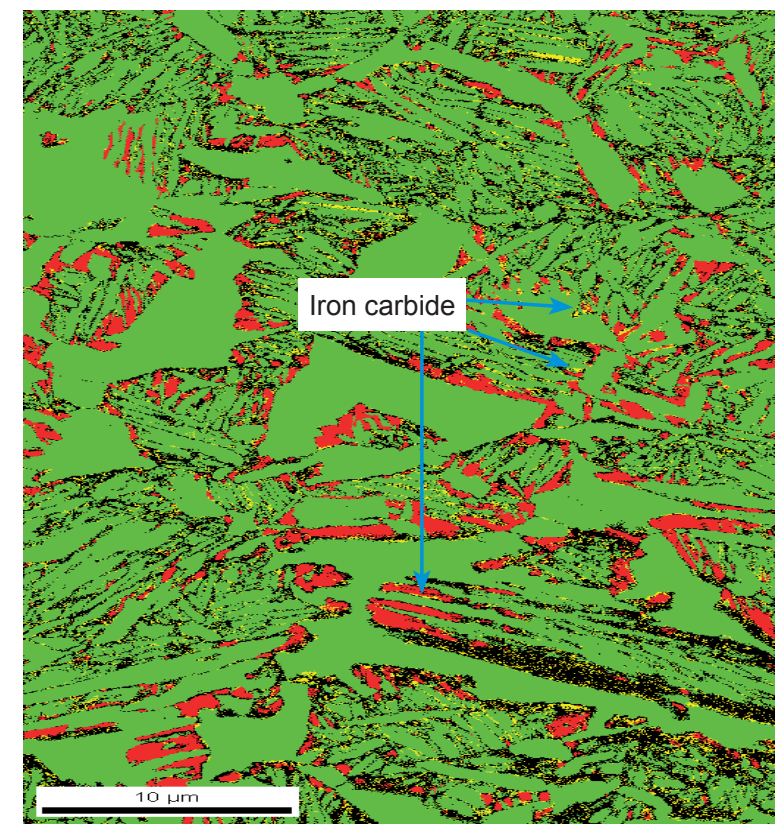

Fig. 9. Showing Iron carbide precipitate (yellow dots) at ferrite /austenite interface [8]

Thus, the precipitation of cementite results in a rise in the volume fraction of the acicular ferrite. The growth of the ferrite is diffusionless; however, any excess carbon in the supersaturated ferrite soon partitions into the residual austenite or precipitates within the ferrite in the form of carbides [18, 19]. It was also identified that the average cell size of the ferrite also starts reducing very significantly starting at the seventh hour of the 
holding period. This effect is attributed to the start of the Stage-II reaction that results in the dissociation of $\gamma_{\mathrm{hc}}$ into ferrite and carbides.

The volume fraction remains nearly constant up to $6 \mathrm{~h}$; further on, it starts to decline due to the start of carbide precipitation. Hence, the transformation interval of $6 \mathrm{~h}$ is the limit between the second and third transformation segments. Therefore, it is confirmed that, during the isothermal transformation of the Dl in the first segment, the volume fraction of carbon stabilized the austenite, and the average cell size of the ferrite increases as the isothermal reaction proceeds to $3 \mathrm{~h}$. In the second segment, it reaches its maximum and then remains approximately constant (3-6 h). Eventually at the third segment, the volume fraction of the austenite as well as the ferrite cell size reduces due to the dissociation of C-stabilized austenite into ferrite and iron carbide (7-8 h). Hence, it is concluded that the range of the isothermal transformation duration is divided into three distinct segments, and the optimum isothermal duration for $\mathrm{Dl}$ austempered at $250^{\circ} \mathrm{C}$ is obtained during the second segment (which ranges from $3 \mathrm{~h}$ to $6 \mathrm{~h}$ ).

\section{DI austempered at $400^{\circ} \mathrm{C}$}

At a higher temperature, the nucleation rate is slow, but the diffusion rate is fast; accordingly, fewer ferrite cells nucleate and grow fairly, leading to a coarser cell size. This effect is evident in Figure 3. As already mentioned, the austempering transformation begins with the nucleation of ferrite, and its growth, preferentially at the graphite nodule which is the potential site of nucleation. The findings given in Table 2 as well as the graphs shown in Figure 10 point out that, at $2 \mathrm{~h}$, the concentration of carbon in the austenite is $2.025 \mathrm{wt} . \%$, and the corresponding lattice parameter size is $3.637 \AA$.

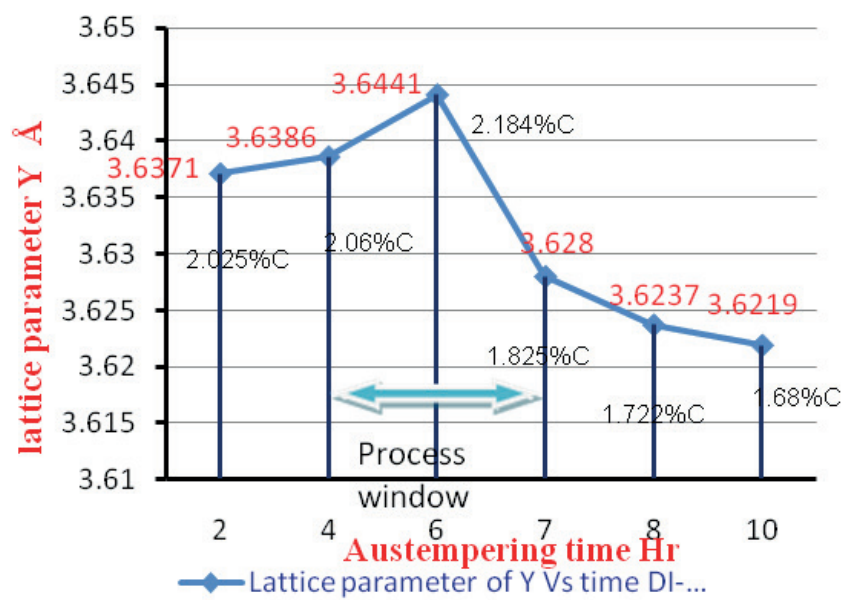

Fig. 10. Dependence of austenite lattice parameter size and ' $C$ ' content in austenite on Austempering Transformation Time 
For DI austempered at $400^{\circ} \mathrm{C}$, the calculated values of the austenite lattice parameter, its carbon concentration, the volume fractions of stabilized austenite, as well as the ferrite for the considered transformation durations are reported in Table 2. Figure 10 shows the effect of austempering time on the lattice parameter and carbon content of the austenite at $400^{\circ} \mathrm{C}$.

The diffusion of carbon atoms from the areas of ferrite into the austenite took place due to the low solubility of the carbon in the ferrite; therefore, carbon concentration in the austenite $\gamma$ increases from $2.025 \mathrm{wt} . \%$ to $2.06 \mathrm{wt} . \%$ (see Tab. 2 and Fig. 10) as the transformation progresses from $2 \mathrm{~h}$ to $4 \mathrm{~h}$. The gradual increase in carbon content of the austenite leads to a rising of the stabilized austenite fraction from $19.34 \%$ to $23.27 \%$ (Fig. 11); correspondingly, the lattice parameter increases from $3.637 \AA$ to $3.638 \AA$ (see Fig. 10 and Tab. 2).

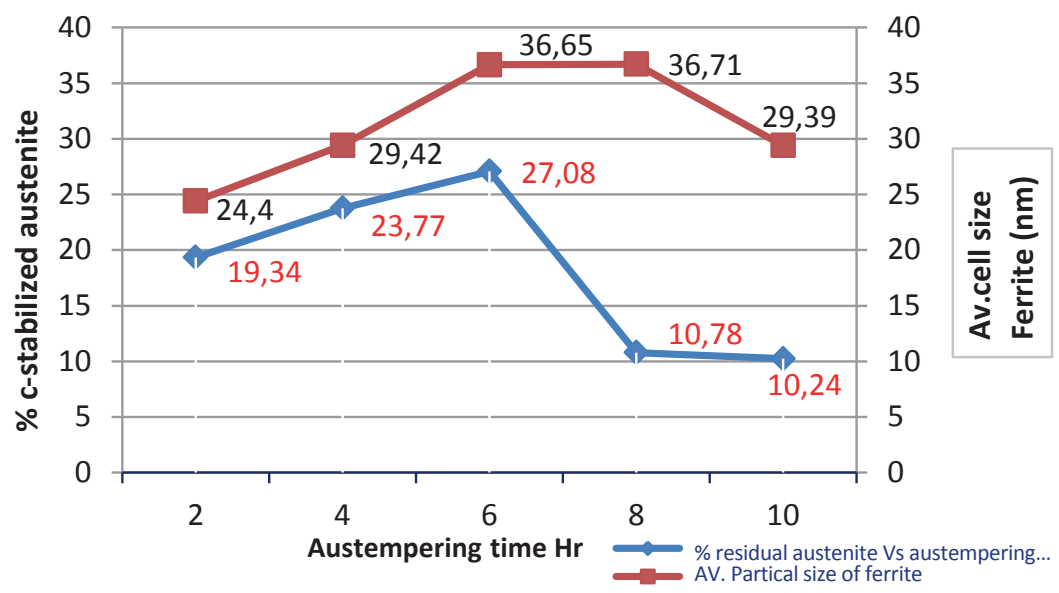

Fig. 11. Dependence of \% C-stabilized austenite and average cell size of Ferrite on Austempering Transformation Time

At $2 \mathrm{~h}$ of transformation duration, the microstructure of the ADI comprises a highvolume fraction of ferrite (65.66\%) and a little martensite, with a moderate content of C-stabilized austenite resulting in a matrix hardness of $482 \mathrm{HV} 10$. With an increase in duration to $4 \mathrm{~h}$, the matrix transformed to a structure that has improved austenite and reduced ferrite contents (61.23\%) with almost no shreds of evidence of martensite, resulting in a reduction of the matrix hardness to 455 HV10. The XRD patterns of the specimen austempered at $400^{\circ} \mathrm{C}$ under investigation are shown in Figure 12. As the austenite becomes thermally stable with carbon, a negligible amount of martensite is observed when the DI is air cooled to room temperature after an isothermal holding 
as compared to $\mathrm{DI}$ austempered at $250^{\circ} \mathrm{C}$. Hence, a transformation duration of $4 \mathrm{~h}$ is specified as the dividing limit between the first and second transformation segments (see Fig. 10).

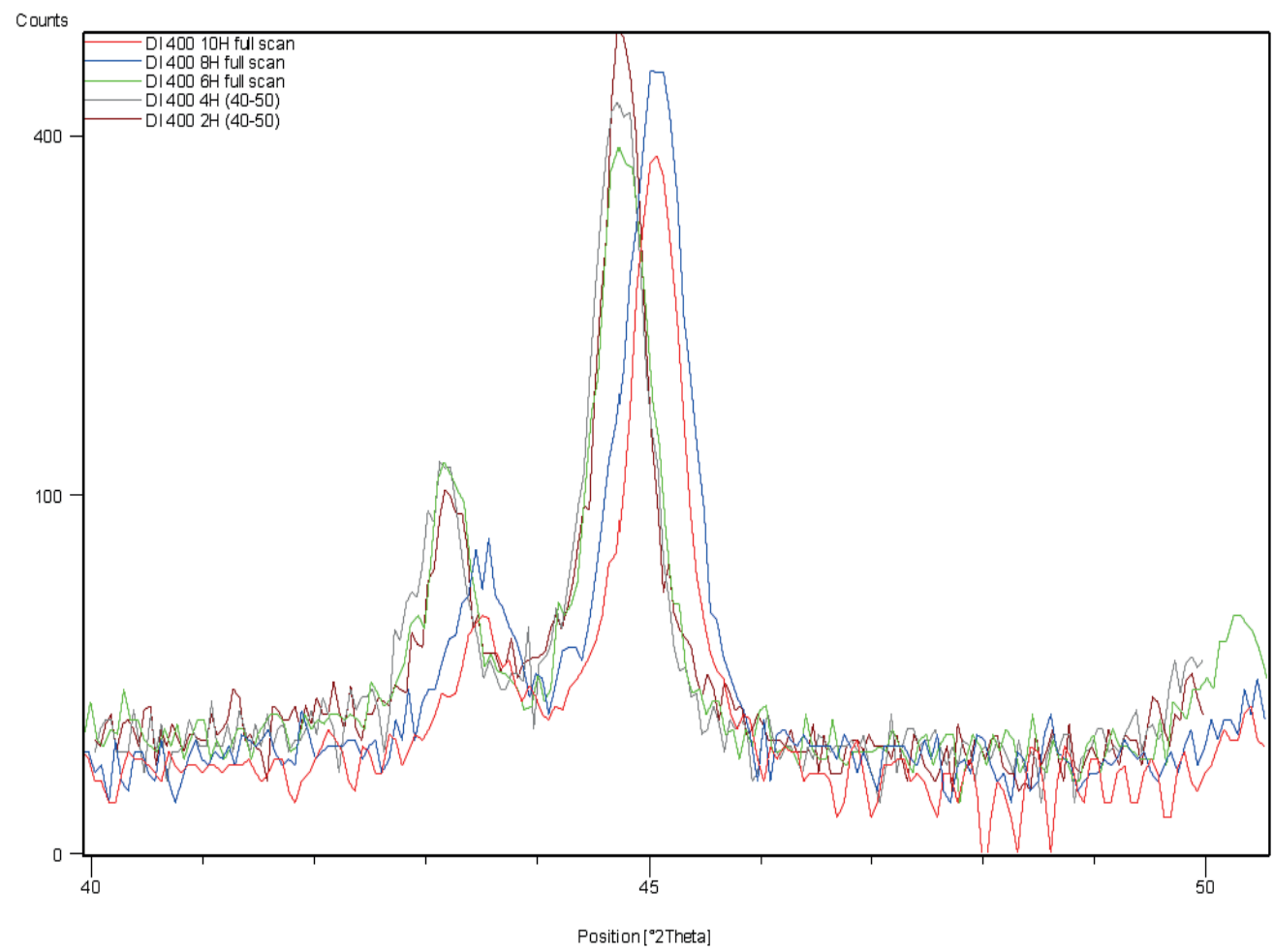

Fig. 12. XRD patterns of specimen austempered at $400^{\circ} \mathrm{C}$

Further, as a transformation dwell time of $6 \mathrm{~h}$ is reached, the $\gamma$ solid solution contains a nearly saturated content of carbon by now (approximately $2.184 \mathrm{wt} . \%$ ) with an increase in the lattice parameter size to $3.644 \AA$ A Due to the stabilization of austenite and lowering of Ms temperature below room temperature at this duration, the martensitic transformation did not occur during cooling. Hence, the microstructure of the ADI obtained at $6 \mathrm{~h}$ comprises the highest amounts of stabilized austenite content (27.08\%), with a much-coarser ferritic cell $(36.65 \mathrm{~nm})$ and the lowest ferrite content $(57.92 \%)$, resulting in the lowest hardness $(432 \mathrm{HV} 10)$ of the specimen. In the transformation period ranging from $4 \mathrm{~h}$ to $6 \mathrm{~h}$, the ADI matrix contains a very high amount of the carbon stabilized austenite without martensite and iron carbides (see Tab. 2 and Fig. 10), which is accepted to be the most-favored microstructure of $A D I$, offering unique properties such as toughness coupled with strength. The microstructure with the maximum austenite content is shown in Figure 13. 


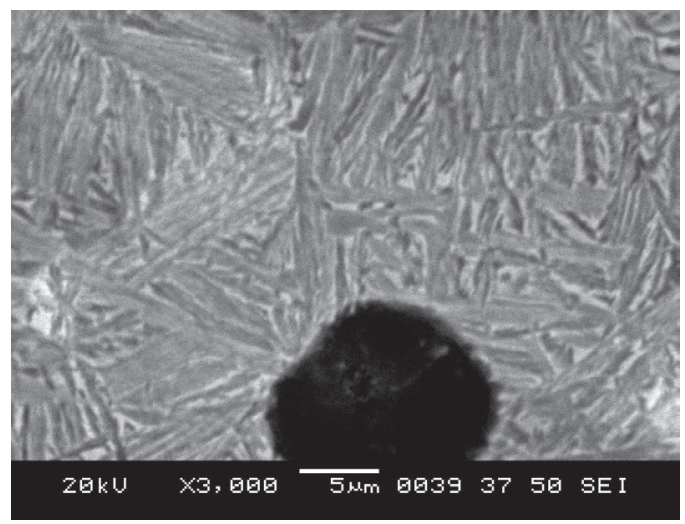

Fig. 13. Complete ausferritic structure obtained at DI-400 at $6 \mathrm{~h}$ of austempering duration

Hence, beyond $4 \mathrm{~h}$ of isothermal transformation up to a $7 \mathrm{~h}$ duration, it is observed that:

- the lattice parameter and carbon content of the austenite essentially remain unvarying (i.e., $\% C=2.03 \pm 0.16$ and $\alpha_{\gamma}=6.634 \pm 0.007$ );

- the content of the $\mathrm{C}$-stabilized austenite in essence stays steady (i.e., \%C-stabilized austenite $=25.42 \pm 1.65$ );

- average cell size of ferrite, keep on constant (i.e., average grain size of ferrite $=34.2$ $\pm 2.51 \mathrm{~nm}$ );

- the hardness of the specimens also almost remains stable $(\mathrm{HV} 10=452 \pm 18)$ in this segment; this duration of austempering transformation from $4-7 \mathrm{~h}$ is known as the optimum isothermal transformation period.

Now, the driving force for the further transformation of austenite into the ferrite is almost negligible (due to the supersaturation of carbon). Therefore, after $7 \mathrm{~h}$, the volume fraction of the stabilized austenite reduces as a consequence of the continuing transformation into the ferrite and iron carbide. When the transformation dwell time of $6 \mathrm{~h}$ is exceeded, the austenite lattice parameter starts decreasing a little bit (Tab. 2). This reduction is an indication of iron carbide precipitation on the bainitic ferrite/austenite interface. Iron carbide precipitates were detected in the XRD patterns of the specimen austempered at $7 \mathrm{~h}$ and $8 \mathrm{~h}$ (Figs. 8 and 12). It was also observed that the average ferritic cell size also starts reducing onwards of $7 \mathrm{~h}$ of holding (Fig. 11) due to the start of the Stage-II reaction. Accordingly, at $8 \mathrm{~h}$ of the holding period, the microstructure consists of a low volume fraction of austenite (10.78\%) and high content of ferrite $(74.22 \%)$ as well as carbides, resulting into another increase in hardness (491 HV10).

Hence, at a higher austempering temperature, it is also confirmed that the range of the isothermal transformation duration is split into three different segments, and the optimum isothermal duration for the $\mathrm{Dl}$ austempered at $400^{\circ} \mathrm{C}$ ranges from $4 \mathrm{~h}$ to $7 \mathrm{~h}$. 


\subsection{Comparison of isothermal transformation between DI austempered at austempering temperatures of $250^{\circ} \mathrm{C}$ and $400^{\circ} \mathrm{C}$}

The austempering temperature influences the driving force for austenite/ferrite transformation; in this way, it ends up in completely different sizes of ferrite needles and different kinetics of the ausferrite transformation. The average cell size of the ferrite obtained at $400^{\circ} \mathrm{C}$ for all austempering periods was found to be much higher than that of the DI austempered at $250^{\circ} \mathrm{C}$ (Tab. 2). At the higher temperature, the nucleation rate of the ferrite is less; however, the diffusion rate was high. Consequently, a fewer number of cells nucleate and grow reasonably, resulting in a coarser cell size. This effect is evident in Figure 3 , which shows the impact of austempering time on the average cell size of ferrite austempered at $250^{\circ} \mathrm{C}$ and $400^{\circ} \mathrm{C}$. Similarly, the volume fraction of the carbon-stabilized austenite was found to be greater at higher austempering temperature. The first reason for this is the lower quantity of ferrite to be formed due to less ferrite nucleation; hence, a greater amount of austenite remained untransformed. The other reason is that, at higher temperatures, the austenite gets stabilized due to the higher diffusion rate of the carbon; hence, more austenite is retained. This effect is evident in Figure 14, which illustrates the effect of austempering time on the residual austenite content austempered at $250^{\circ} \mathrm{C}$ and $400^{\circ} \mathrm{C}$.

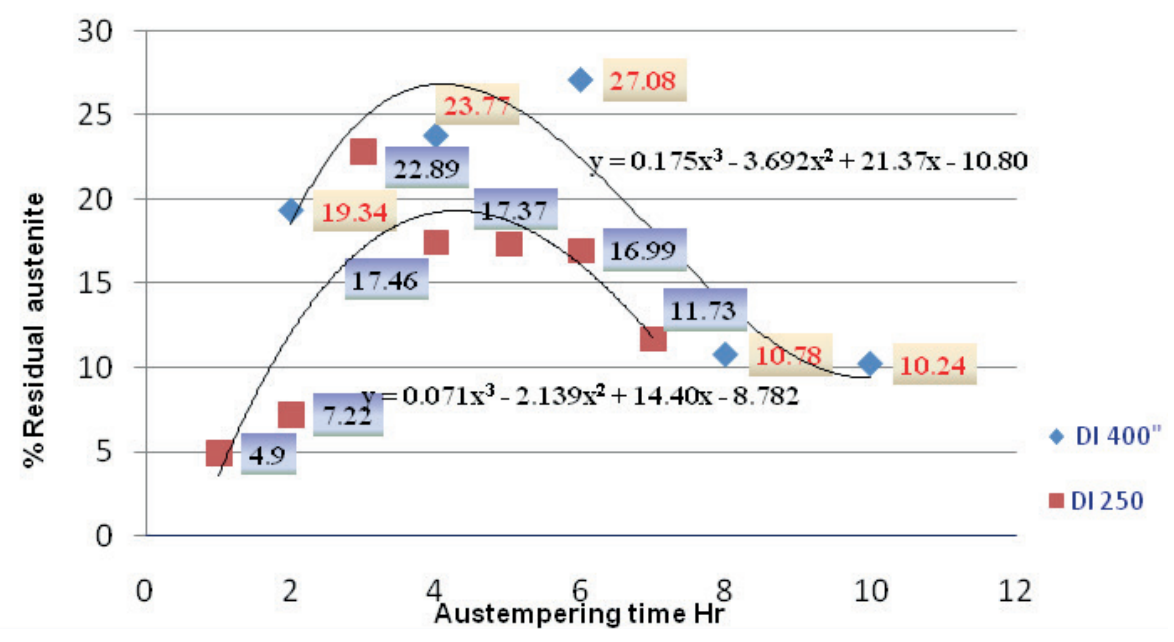

Fig. 14. Effect of austempering time on residual austenite content austempered at $250^{\circ} \mathrm{C}$ and $400^{\circ} \mathrm{C}$

Because of the supersaturation of austenite with high carbon content at the higher temperature in the ADI, the lattice parameter of the austenite was found to be more than that of the ADI austempered at the lower temperature. 
Due to the slow diffusion rate at $250^{\circ} \mathrm{C}$, the carbon is trapped in the ferrite, which makes the presence of the transitional carbides throughout the transformation within the ferrite cell (which isn't discovered in the DI austempered at $400^{\circ} \mathrm{C}$ ).

The optimum isothermal transformation period at the lower temperature $\left(250^{\circ} \mathrm{C}\right)$ was found in a shorter amount of time (3-6 h), whereas it expands from $4 \mathrm{~h}$ to $7 \mathrm{~h}$ for the higher temperature. At the lower austempering temperature, the Stage-I reaction rate is accelerated due to the higher driving force [7]; hence, ausferritic transformation begins early, and process window eventually starts much earlier (i.e., at $3 \mathrm{~h}$, compared to higher one that starts at $4 \mathrm{~h}$ ). Many researchers suggest the limiting range of Mn would be $0.18-0.5 \%$ [20]. But during solidification, $\mathrm{Mn}$ segregates to the cell boundaries where it forms carbides and retards the austempering reaction. Hence, it is advisable to restrict the manganese level in ADI to less than $0.3 \%$ [21]. The Mn level present in the material under investigation is $0.44 \%$, which is little higher than normal. This could be the reason for the extended duration required for the start of the process window.

The optimum process window is the duration of the isothermal transformation, where the matrix consists of a very negligible amount of martensite and iron carbide. Martensite was obtained when the austempering duration was short and the austenite does not become thermally stable by the required carbon content. Whereas carbides are formed due to extended isothermal transformation due to the dissociation of high carbon austenite into the ferrite and iron carbides, the system approaches the metastable equilibrium between the ferrite and iron carbide [7]. This dissociation involves microstructural as well as compositional change and, hence, requires a large activation barrier. During the transformation at the lower temperature, the transitional carbides $\left(\mathrm{Fe}_{2} \mathrm{C}, \mathrm{Fe}_{7} \mathrm{C}_{3}\right)$ are present, and the magnitude of grain boundary area is increased. At such a site, the creation of a nucleus will either relax the lattice strain or destroy a defect, both of which liberate energy and reduce the activation barrier (net free energy to form the nucleus) required for their precipitation [22]. Due to the decrease in the activation barrier, the precipitation of iron carbide initiates at a short austempering duration. Hence, the optimum process window ends at the shorter period of $6 \mathrm{~h}$ at the lower austempering temperature. Transitional carbides were absent at the higher temperature; hence, to overcome the matrix's incompatibility and higher activation barrier, a longer transformation period is required. Ultimately, an extended process window of $4 \mathrm{~h}$ to $7 \mathrm{~h}$ is obtained. The other reason for this is due to an increase in the diffusion distance. The number of cells and cell boundaries are more at the lower austempering temperature, and less time will be required for the diffusion of carbon at the ferrite/austenite interface. Thus, a shorter period of time is required to start the dissociation of high carbon austenite into the ferrite and carbides and vice versa.

\section{Conclusions}

The volume fraction of carbon stabilized austenite obtained at a higher austempering temperature was found to be greater compared to that observed at a lower 
austempering temperature. Similarly, the lattice parameter of the austenite and the ferritic cell size were also larger than the corresponding parameter at the lower austempering temperature. On the other hand, the hardness was found to be lower in this case.

The range of the isothermal transformation duration is divided into three distinct segments. The optimum isothermal duration for $\mathrm{Dl}$ austempered at $400^{\circ} \mathrm{C}$ is obtained from 4 to $7 \mathrm{~h}$. For Dl austempered at $250^{\circ} \mathrm{C}$, this ranges from $3 \mathrm{~h}$ to $6 \mathrm{~h}$.

It is verified that, at the end of the austempering reaction, the microstructure consists of not only ausferrite but additionally precipitated iron carbides. The amounts of ferrite and austenite increase, whereas that of the martensite decreases with austempering time.

During the transformation at the lower temperature where the transitional carbides such as $\left(\mathrm{Fe}_{2} \mathrm{C}, \mathrm{Fe}_{7} \mathrm{C}_{3}\right)$ are present and the diffusion distance is smaller, an optimum process window is obtained at a shorter period of $3 \mathrm{~h}$ to $6 \mathrm{~h}$, while transitional carbides were absent at the higher temperature; hence, to overcome the matrix incompatibility, a greater period is required, and the obtained process window is from $4 \mathrm{~h}$ to $7 \mathrm{~h}$.

\section{Acknowledgments}

The authors are thankful to Prof. S.U. Pathak, Department of Metallurgy and Materials Engineering, VNIT Nagpur, for their guidance and support. We are obliged to Principal, Dr. Patel Bhaskar, and the Management of Kavikulguru Institute of Technology and Science, Ramtek, for their support.

\section{References}

[1] Ductile Iron Data for Designing Engineer. Rio Tinto Iron \& Titanium Inc., Montreal 1990

[2] Metzioff K.E., Fang L.Y., Loper C.R.: AFS Transactions, 47 (1995), 103-112

[3] Voigt R.C., Loper C.R.: Austempered ductile iron - process control and quality assurance. Proceedings of the 1st International Conference on Austempered Ductile Iron, ASM, (1984), 83-90

[4] Janowak J.F., Gundlach R.B.: Development of a ductile iron for commercial austempering. Transactions AFS, 86 (1983), 377-386

[5] Věchet S., Kohout J., Bokůvka O.: Fatigue properties of nodular cast iron. Únavové vlastnosti tvárné litany, Zilinska univerzita, Zilina 2002

[6] Rouns T.N., Rundman K.B.: Constitution of austempered ductile iron and the kinetics of austempering. AFS Transactions, 95 (1987), 851-874

[7] Tanaka Y., Kage H.: J. Development and Application of Austempered Spheroidal Graphite Cast Iron. Materials Transactions, 33, 6 (1992), 543-557

[8] Parhad P., Likhite A., Bhatt J., Peshwe D.: The Effect of Cutting Speed and Depth of Cut on Surface Roughness During Machining of Austempered Ductile Iron. Transactions of the Indian Institute of Metals, 68,1 (2015), 99-108

[9] Senczyk D.: Laboratorium z rentgenografii structuralnej. Politechnika Poznańska, Poznań 1974

[10] Aranzabal J., Gutierrez I., Rodriguez-Ibabe J.M., Urcola J.J.: Influence of the Amount and Morphology of Retained Austenite on the Mechanical Properties of an Austempered Ductile Iron. Metallurgical and Materials Transactions A, (1997), 1143-1156 
[11] Cullity B.D.: Elements of X-Ray Diffraction. Addison-Wesley Publishing Company, Reading, MA, USA 1956.

[12] Keough J.R.: An ADI Market Primer. Foundry Management and Technology, 123, 11 (1995), 28-31

[13] Seshan S.: ADI - the under-exploited wonder cast iron. Transaction of Indian Foundryman, National Seminar, SG-50. Golden Jubilee Celebration, 84-92 (1998)

[14] Fuller A.G.: Effects of Graphite Form on Fatigue Properties of Pearlitic Ductile Irons. AFS Transactions, 77-102A (1997), 527-538

[15] Navara E., Zimba J.: Ausferritic Ferrous Alloys - a Challenge to Industry and Research. Acta Metallurgica Slovaca, 10, 1 (2004), 244-252

[16] Christian J.W.: The Theory of Transformations in Metals and Alloys. Pergamon Press, Oxford - New York $1965,778-786$

[17] Bhadeshia H.K.D.H.: Bainite in steels: transformations, microstructure and properties. Institute of Materials, London 1992

[18] Takahashi M., Bhadeshia H.K.D.H.: A Model for the Microstructure of Some Advanced Bainitic Steels. Materials Transaction of the Japan Institute of Metals, 32 (1991), 689-696

[19] Thomson R.C., James J.S., Putman D.C.: Modelling microstructural evolution and mechanical properties of austempered ductile iron. Materials Science and Technology, 16, 11-12 (2000), 1412-1419

[20] Ductile Iron Society: Ductile Iron Data for Design Engineers. http://www.ductile.org/didata/pdf/didata2.pdf, 9

[21] Durhamfoundary, austempered ductile iron castings. http://www.durhamfoundry.com/austempered_ ductile_iron.htm

[22] Polishetty A.: Machinability and microstructural studies on phase transformations in Austempered Ductile Iron. A thesis submitted to Auckland University of Technology, Aucland 2011 